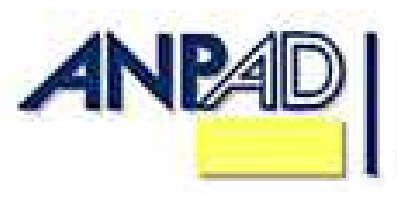

Available online at http://www.anpad.org.br/bar

BAR, Rio de Janeiro, v. 9, Special Issue, art. 4, pp. 60-77, May 2012

\title{
The Entrepreneurial Orientation-Dominant Logic-Performance Relationship in New Ventures: an Exploratory Quantitative Study
}

\author{
Héctor Montiel Campos* \\ E-mail address: hector.montiel@udlap.mx \\ Universidad de las Américas Puebla \\ Puebla, Mexico. \\ José Pablo Nuño de la Parra \\ E-mail address: pablo.nuno@upaep.mx \\ UPAEP University \\ Puebla, Mexico.
}

Francesc Solé Parellada E-mail address: pacosoleparellada@inssl.e.telefonica.net Polytechnic University of Catalunya Barcelona, Spain.

Copyright (C) 2012 Brazilian Administration Review. All rights reserved, including rights for translation. Parts of this work may be quoted without prior knowledge on the condition that the source is identified. 


\begin{abstract}
Entrepreneurial Orientation (EO) has received substantial conceptual and empirical attention, representing one of the few areas in entrepreneurship research in which a cumulative body of knowledge is developing. Nonetheless, an important message from past research is that simply examining the direct effect of EO on firm performance provides an incomplete picture, especially in the case of new ventures. This study examined the influence of Dominant Logic (DL) on the relationship between EO and firm performance. Results based on a sample of 149 new manufacturing ventures indicated that DL mediates the EO-performance relationship, and risk taking, aggressiveness and innovativeness had the highest correlations with the internal and external conceptualization of DL. The empirical evidence suggests that new ventures must foster DL implementing appropriate strategic processes in order to maximize the effect of $\mathrm{EO}$ on performance.
\end{abstract}

Key words: entrepreneurial orientation; dominant logic; performance; new ventures. 


\section{Introduction}

As the entrepreneurship paradigm expands, it is increasingly acknowledged that organizations, per se, can behave in entrepreneurial manners (Dess, Lumpkin, \& McGee, 1999). For Stevenson and Jarrillo (1990), a firm is to be labeled as entrepreneurial if its behaviors and processes are oriented towards the recognition, assessment and exploitation of opportunities, independently of its directly controlled resources. The concept of Entrepreneurial Orientation (EO) is part of this perspective and relies on dimensions that allow us to characterize and test the entrepreneurial behavior of a given firm.

EO has emerged as a major construct in the strategic management and entrepreneurship literature over the years (Rauch, Wiklund, Lumpkin, \& Frese, 2009). Thus, empirical studies have largely found that firms with more EO perform better (Wiklund, 1999; Zahra \& Covin, 1995). However, the magnitude of the relationship seems to vary from one study to another (Wiklund \& Shepherd, 2005). Indeed, these suggestions form the basis for the interest in studying the relationship between EO and performance (D. Miller, 1983).

By simply examining the direct EO-performance relationship, our scope on performance is limited (Rauch et al., 2009). This urges future research to control internal and external contingent factors in the examination of the EO-performance relationship (Covin, Green, \& Slevin, 2006; Lumpkin \& Dess, 2001; Wiklund, 1999; Wiklund \& Shepherd, 2003; Zahra, 1993). A focus on such research is warranted because it may shed some needed light on the topic of how new ventures can effectively manage firm-level entrepreneurial behavior.

It is generally acknowledged that strategic decisions are influenced by the beliefs, value structures and management philosophies of strategists. Andrews (1980) has argued that top management's values and philosophies are the major determinants of competitive choices. This exploratory work supports the assumption of the predominant role of the founder-manager's strategic philosophy in the emergence and persistence of a strong entrepreneurial culture likely to shape the firm's collective behavior (Fayolle, Basso, \& Legrain, 2008). Prahalad and Bettis (1986) called this the Dominant Logic (DL) of the firm.

This study builds on the existing body of work and, more specifically, conceptualizes DL as a mediator of the EO-performance relationship. This kind of relationship requires more research and is especially important in the context of new ventures. The objective of this study is to evaluate the EODL-performance relationship, drawing on data collected from 149 new ventures in Mexico. It was designed to determine whether DL moderates the relationship between EO and firm performance and, if so, to identify what type of moderating effect it has on this relationship. More specifically, our research question is: Is the EO-performance relationship mediated by DL in new ventures? By addressing this question, this study aims to cross-fertilize entrepreneurship and strategic management literature (Davidsson, Low, \& Wright, 2001).

In the next section, we introduce the EO and DL concepts and the implications on new ventures. We then go on to describe the research method used in the study, and the analytic techniques used in our research. Finally, we report our findings and discuss their implications.

\section{Theoretical Framework and Hypotheses}

\section{Conceptualization of EO and DL}

EO is revealed through firm-level characteristics as summarized by D. Miller (1983, p. 773): "An entrepreneurial firm is one that engages in product market innovation, undertakes somewhat risky ventures, and is first to come up with proactive innovations, beating competitors to the punch". The 
conceptualization of EO has been the focus of systematic inquiry in literature (Covin \& Slevin, 1991; Covin et al., 2006; Dess et al., 1999; Lumpkin \& Dess, 1996; Lyon, Lumpkin, \& Dess, 2000), and several key dimensions of the construct have emerged. Entrepreneurship researchers have adopted D. Miller and Friesen's (1982) original measurement of organizational-level entrepreneurship or slightly modified D. Miller's measurement (1983). Based on Miller's conceptualization, three dimensions of EO have been identified and used consistently in literature: innovativeness, risk taking and proactiveness.

Lumpkin and Dess (1996) explain the three characteristics and suggest that innovativeness is a firm's tendency to engage in and support new ideas, novelty, experimentation and creative processes that may result in new products, services or technological processes. Risk taking involves taking bold actions by venturing into the unknown, borrowing heavily, and/or committing significant resources to ventures in uncertain environments. Proactiveness is an opportunity-seeking, forward-looking perspective characterized by the introduction of new products and services ahead of the competition and acting in anticipation of future demand.

Drawing on D. Miller's (1983) definition and prior research, Lumpkin and Dess (1996) identified competitive aggressiveness and autonomy as additional components of the EO construct. Competitive aggressiveness is the intensity of a firm's effort to outperform rivals and is characterized by a strong offensive posture or aggressive responses to competitive threats. Autonomy refers to the ability to work independently, make decisions and take actions aimed at bringing forth a business concept or vision and carrying it through to completion.

Most recently, Rauch, Wiklund, Lumpkin and Frese (2009) based on a meta-analysis of the cumulative knowledge on the relation between EO and business performance, conclude that the EOperformance relationship is moderately high and that firms benefit from EO. Research indicates that performance can be improved when key variables are correctly aligned (Naman \& Slevin, 1993). This is the basic premise of the contingency theory, which holds that the relationship between two variables depends on the level of a third variable. Introducing moderators into bivariate relationships helps to reduce the potential for misleading inferences and permits a more precise and specific understanding of contingency relationships (Rosenberg, 1968).

The literature discusses a number of variables that potentially moderate the EO-performance relationship. There is little consensus on what constitutes suitable moderators; however, internal variables such as knowledge (Wiklund \& Shepherd, 2003), learning orientation (Wang, 2008), network capability (Walter, Auer, \& Ritter, 2005), strategic processes (Covin et al., 2006), plus various contextual variables such as national culture (Richard, Barnett, Dwyer, \& Chadwick, 2004), access to financial resources (Wiklund \& Shepherd, 2005) and hostile environments (Zahra \& Covin, 1995; Zahra \& Garvis, 2000), have been included in studies of EO. Nevertheless, so far, a firm's DL has been a missing link in the study of the EO-performance relationship.

In 1986, Prahalad and Bettis introduced the concept of DL as "the way in which managers conceptualize the business and make critical resource allocation decisions". Prahalad and Bettis (1986, p. 488) suggested that the way top managers deal with increasing variety of strategic decisions in a firm, caused by acquisitions or structural changes in the firm's core business, depends on the cognitive orientation of those top managers. The authors noted that DL is stored via shared schemas and cognitive maps and is influenced by managers' previous experiences.

In a reflective article on their earlier work, Bettis and Prahalad (1995) defined DL as a filter through which managers consider relevant data. According to the extended view of DL as an information filter, C. Miller, Burke and Glick (1998) mention that the top managers focus their attention on data that offers support for their current DL while other potentially important data may not be recognized. This filtering mechanism is seen to have an impact on strategy development and thereby on the strategic direction of the firm. Furthermore, this conceptualization focuses on information processing in relation to information or data about the past or current environment, but does not provide an explicit link to decisions about future strategies. 
When the top managers decide on which strategies to pursue in the future, DL functions as a lens for viewing that future and thus restricts the range of imaginable options (Grant, 1988). When deciding upon a strategy, DL allows only for decisions that are in accordance with it, meaning that the basic rules of the business in which the firm is operating are not questioned for the future. The DL is strengthened or questioned depending on the perceived success or failure of the implemented strategy (Krogh, Erat, \& Macus, 2000).

The shortage of academic discussion on DL may also partly be attributed to the difficulty of operationalizing the concept for empirical research. Variants of Prahalad and Bettis's (1986) notion of DL have appeared in strategy process literature. The various formulations converge around "the way in which managers conceptualize the business" (Prahalad \& Bettis, 1986, p. 489). DL has been discussed in terms of consensus behavior among homogeneous top management team members (Krogh et al., 2000), international diversification (Douglas, 2005) strategic formulation in complex systems (Bettis \& Prahalad, 1995), acquisition strategy (Coté, Langley, \& Pasquero, 1999), joint ventures (Lampel \& Shamsie, 2000), global learning in multinational corporations (Halvorsen, 2006) and organizational innovation (Bouwen \& Fry, 1991). The concept of DL, in short, assumes that the business world for a manager is neither pre-given, nor predefined, as in the field of entrepreneurship (McMullen \& Shepherd, 2006). Rather, cognition is the creative part of bringing forth a subjective world. There is no right world to be represented, only a point of observation for selected data (Krogh \& Roos, 1996).

\section{EO, DL and firm performance in new ventures}

According to D. Miller (1983), the entrepreneurial label is most defensible as a descriptor of established firms. However, the technological development and scarcity of resources alone endanger stability and the predictability of the market. Even if EO is often developed by large established corporations, sometimes people start new ventures to create and exploit entrepreneurial opportunities, making the creation of new ventures a very important mechanism through which innovation is exploited (Shane, 2009).

New ventures lack capabilities, market power and other resources that established firms have. However, in both new ventures and existing firms, entrepreneurship carried out in the pursuit of business opportunities spurs business expansion, technological progress and wealth creation (Aloulou \& Fayolle, 2005; Shane \& Venkarataman, 2000). To face fierce competition, new ventures must review practices and actively search for new ways to practice flexibility, increase their capacity for innovation and show more competitiveness (Bhuian, Menguc, \& Bell, 2005; Ireland, Hitt, \& Sirmon, 2003). Such characteristics are associated with improved firm performance in today's business environments, in which product and business model life cycles are shortened (Hamel, 2000), and where future profit streams from existing unstable operations. Therefore, businesses need to constantly seek out new opportunities (Prahalad \& Krishnan, 2008).

Understanding the EO-DL-performance relationship in new ventures is particularly important for several reasons. Firstly, considering the level of analysis issued, a firm-level model of entrepreneurship is appropriate because entrepreneurial effectiveness is arguably a firm-level phenomenon (Covin \& Slevin, 1991). This is to say that an entrepreneur's effectiveness can be measured in terms of his or her firm's performance. Secondly, and related to the first point, firm performance is a function of organizational - as well as individual - level behavior. Admittedly, individual-level behavior on the part of the founder-manager may affect an organization's actions, and in many cases the two will be synonymous (Brown, Davidsson, \& Wiklund, 2001). This line of argument clearly places the founder-manager at the center of any model of firm behavior (Dess et al., 1999), and the new ventures will not survive if they do not maintain an entrepreneur's proficiency (Drucker, 1985). That means that EO is useful for predicting the nature and success of a new venture, and it may be contingent on internal factors, such as the DL (Covin \& Slevin, 1991; Lumpkin \& Dess, 1996). This is consistent with Gartner's (1985) perspective regarding entrepreneurship as a multidimensional phenomenon. 
Finally, a behavioral model of entrepreneurship is appealing because behavior is manageable. Firm-level entrepreneurial behavior is affected by, and therefore can be managed through, the creation of particular organizational strategies, structures, systems and cultures (Hamel \& Prahalad, 1994). As such, a behavioral model of entrepreneurship allows for considerable managerial intervention, and the entrepreneurial process can be viewed as much less serendipitous, mysterious and unknowable (Covin \& Slevin, 1991). In this perspective, if DL moderates the relationship between EO and firm performance, we could have a better insight into entrepreneurship. Given the previous discussion, this study hypothesizes that:

The EO-performance relationship in new ventures is mediated by DL; EO has a positive impact on DL that, in turn, has a positive impact on firm performance.

\section{Research Method}

\section{Sample and data collection}

For data collection, a self-administered survey questionnaire was developed for this study. Prior to the final questionnaire design, five exploratory interviews were conducted with founder-managers. The survey instrument incorporated the feedback and suggestions from the exploratory interviews with which the questionnaire was refined. The sample of this study is drawn from different places in Mexico. A sample of 853 new firms was selected from the Mexican Business Information System. Each firm has the following characteristics: (a) It initiated commercial operations three to five years prior to this study - a criterion for new venture (Kazanjian \& Drazin, 1990; Littunen, Storhammar, \& Nenonen, 1998). (b) Each firm has between 11 and 40 employees -a criterion for small firms defined by the Ministry of the Economy in Mexico. (c) All firms operate in the industrial manufacturing segment.

Eight hundred fifty three questionnaires were mailed to the founder-managers with a cover letter. A total of 158 questionnaires were received: an 18.5\% response rate. After discounting non valid and incomplete responses, 149 usable responses remained and were subsequently used in the analysis. The ANOVA test was performed to examine possible non-response bias, as suggested by Armstrong and Overton (1977). The results revealed that there was no evidence of systemic nonresponse bias.

\section{Measures}

The data analysis of this study follows a two-step procedure: assessing measurement models using Confirmatory Factor Analysis (CFA), followed by assessing path relationship using Structural Equation Modeling (SEM) (Anderson \& Gerbing, 1988). The model fit was assessed using $\chi^{2} / d f$, Goodness-of-Fit Index (GFI) (Jöreskog \& Sörbom, 1996) and the Comparative Fit Index (CFI) (Bentler, 1992). The threshold for $\chi^{2} / d f$ should be less than 3.0 or less than 2.0 in a more restrictive sense (Premkumar \& King, 1994). Values of GFI and CFI should be over 0.90.

Multiple measures of each of the variables used in this study are drawn from current literature. Although no research has suggested which measure is the best, the aforementioned measures have received support from the research community.

Entrepreneurial orientation. Entrepreneurship researchers have adopted D. Miller and Friesen's (1982) original measurement of organizational-level entrepreneurship or slightly modified D. Miller's measurement (1983) and adopted or extended it with several other studies (Covin \& Slevin, 1991; Dess et al., 1999; Lumpkin \& Dess, 1996). This study based the measure of EO that is now referred to as the Miller/Covin and Slevin scale (Brown et al., 2001). The scale contains items that measure a firm's tendency toward innovativeness, risk taking, proactiveness, aggressiveness and 
autonomy. Wiklund (1999) identified that this measure is a viable instrument for capturing firm-level entrepreneurship. Innovativeness is assessed by asking founder-managers about the product-market and technological aspects of innovation (D. Miller \& Friesen, 1982) and the firm's overall propensity of innovative behavior (Hurt, Joseph, \& Cook, 1977). Firm risk taking is assessed by asking foundermanagers about the firm's propensity to engage in risky projects and preference for bold versus cautious acts to achieve firm objectives (Lumpkin \& Dess, 1996). Proactiveness is assessed by asking founder-managers about the firm's tendency to lead, rather than follow, in terms of developing new procedures, technologies and new products or services (Covin \& Slevin, 1989). Aggressiveness is measured by competitive processes used by founder-managers to pursue rivals or take up new competitors, since its point of reference is competition (Lumpkin \& Dess, 1996). Autonomy is measured by independent action undertaken by founder-managers or teams directed at bringing about a new venture and seeing it to fruition (Lumpkin, Cogliser, \& Schneider, 2009). In total, 14 items were included in the EO scale. Details of the items are included in Appendix - Table A1. A seven-point Likert scale, ranging from strongly disagree to strongly agree, was used to assess the items that measure a firm's tendency toward EO. The mean score was calculated from the average of the 14 items. The higher the score, the more it indicates that the firm demonstrates an EO. CFA test were performed, with EO as a higher-order latent construct, consisting of the five first-order factors. The measurement model resulted in a good fit: $\chi^{2} / d f=2.131, \mathrm{GFI}=0.913, \mathrm{CFI}=0.941$. All loadings were significant $(t>1.96, p<0.001)$, ranging from 0.48 to 0.83 .

Dominant logic. The concept of DL was operationalized as the dominant set of beliefs and premises associated with the management of the firm. This study adopted the category developed by Krogh, Erat and Macus (2000). The category set consists of two dimensions: internal conceptualization (people, culture and product and brand); and external conceptualization (competitor, customers and consumer, and technology). These dimensions are in the spirit of Prahalad and Bettis' (1986) definition concerning DL, and consistent with the formulations proposed by Grant (1988), Ginsberg (1990) and Coté, Langley and Pasqueiro (1999). Internal conceptualization is measured through examining the extent to which the beliefs, values and assumptions of the founder-manager infuse the whole organization and shape the learning experiences of the group members during the start-up stage (Schein, 1983). External conceptualization is assessed by asking founder-managers about their propensity to cope with environmental complexity in order to retain their capacity to act (March, 1994). In total, seven items were included in the DL scale. Details of the items are included in Appendix - Table A2. A seven-point Likert scale, ranging from strongly disagree to strongly agree, was used to assess the way in which the founder-manager conceptualizes business (Bettis \& Prahalad, 1995). The mean score was calculated from the average of the seven items. The higher the score, the more it indicates that the firm demonstrates a DL. CFA tests were performed, with DL as a higherorder latent construct, consisting of the two first-order factors. The measurement model resulted in a good fit: $\chi^{2} / d f=1.958, \mathrm{GFI}=0.937, \mathrm{CFI}=0.901$. The loading of each indicator was significant, ranging from 0.59 to $0.91(t>1.96, p<0.001)$.

Firm performance. The validity of assessing firm performance through subjective measures, such as that adopted here, has been supported by Dess and Robinson (1984). Perceptual measures of performance can be significantly correlated with objective measures and serve as good substitutes in the absence of hard data (Brush \& Vanderwerf, 1992; Cooper, 1993; Covin \& Slevin, 1988). This study subscribes to the view that performance comparisons with competitors reveal important information (Birley \& Westhead, 1990; Wiklund \& Shepherd, 2003). Furthermore, it is possible to control, for the effects of industry-related factors, performance through the use of perceptual measures. For example, $15 \%$ may be considered a high performance in some industries and a low performance in others. Directly comparing business in industries with different performance standards would be misleading. Therefore, three subjective indicators were used to measure firm performance. The respondents were asked to indicate on a seven-point Likert scale, ranging from not at all satisfactory to outstanding, how they would rate the performance of their own firm in relation to that of their main competitors over the past three years on each of the following performance criteria: cash flow from operations, return on capital employed, and sales growth. Details of the items are included in Appendix - Table A3. The mean score was calculated from the average of the three items. The higher 
the score, the more it indicates that the firm shows an outstanding firm performance. The model resulted in a good fit: $\chi^{2} / d f=2.301, \mathrm{GFI}=0.927, \mathrm{CFI}=0.966$. The loading of each indicator was significant, ranging from 0.47 to $0.79(t>1.96, p<0.001)$.

\section{Results and Discussion}

This study relies on self-reported data from single informants and respondents (foundermanager), who were given assurances of their confidentiality and anonymity in order to reduce evaluation apprehension. Moreover, this study conducted the one-factor test (Podsakoff \& Organ, 1986) to examine the common method bias. All variables of the EO, DL and firm performance constructs were entered into an exploratory factor analysis. The results revealed that no single factor emerged from this analysis, nor was there a general factor which could account for the majority of variance in these variables. This indicates that common method bias is not a major problem in this study.

For each construct, the dimensionality of each item was assessed by the loadings and their associated t-ratios (Anderson \& Gerbing, 1988). The results showed that each item loaded significantly on only its respective first-order factor, and subsequently the higher-order construct, without cross-loading to any other first-order factor of the same construct. Reliability was assessed by using coefficient alpha (Peter, 1979). Table 1 shows the summary statistics (means scores, SDs, and Cronbach alpha coefficients, where appropriate) and correlation matrix.

Table 1

\section{Summary Statistics and Correlation Matrix}

\begin{tabular}{|c|c|c|c|c|c|c|c|c|c|c|c|}
\hline Variable & Mean & SD & Alfa & 1 & 2 & 3 & 4 & 5 & 6 & 7 & 8 \\
\hline $\begin{array}{l}\text { Entrepreneurial } \\
\text { Orientation }\end{array}$ & 4.202 & 1.107 & 0.861 & & & & & & & & \\
\hline 1. Innovativeness & 3.410 & 1.311 & 0.78 & 1.000 & $0.38^{*}$ & 0.212 & 0.343 & 0.199 & 0.518 & 0.327 & 0.323 \\
\hline 2. Risk taking & 4.789 & 1.088 & 0.81 & & 1.000 & 0.338 & 0.219 & 0.175 & 0.619 & 0.422 & 0.217 \\
\hline 3. Proactiveness & 4.112 & 1.322 & 0.74 & & & 1.000 & 0.194 & 0.220 & 0.341 & 0.440 & 0.287 \\
\hline 4. Aggressiveness & 4.629 & 1.217 & 0.85 & & & & 1.000 & 0.316 & 0.441 & 0.580 & 0.198 \\
\hline 5. Autonomy & 3.970 & 0.985 & 0.72 & & & & & 1.000 & 0.226 & 0.280 & 0.131 \\
\hline Dominant Logic & 4.740 & 1.056 & 0.79 & & & & & & & & \\
\hline $\begin{array}{l}\text { 6. Internal } \\
\text { conceptualization }\end{array}$ & 4.793 & 1.224 & 0.81 & & & & & & 1.000 & 0.318 & 0.547 \\
\hline $\begin{array}{l}\text { 7. External } \\
\text { conceptualization }\end{array}$ & 4.614 & 1.361 & 0.84 & & & & & & & 1.000 & 0.388 \\
\hline 8. Firm Performance & 4.406 & 1.075 & 0.85 & & & & & & & & 1.000 \\
\hline
\end{tabular}

Note. $N=149$.

*Correlation coefficients are significant at $p<0.001$.

\section{The mediating effect of DL}

This study follows the approach for testing the mediating effect as suggested by MacKinnon, Lockwood, Hoffman, West and Sheets (2002). A full mediating model should be tested with a path from the independent variable (EO) to the mediator (DL) and a path from the mediator (DL) to the dependent variable (firm performance); a direct relationship between the independent variable (EO) and dependent variable (firm performance) is not expected, and hence a direct path does not need to be included. The approach has been supported by MacKinnon et al. (2002). The SEM model in this 
study, consisting of three latent constructs (EO, DL and firm performance as shown in Figure 1) resulted in an adequate fit and the model fit indexes were: $\chi^{2} / d f=2.839, \mathrm{GFI}=0.940, \mathrm{CFI}=0.911$. The loading of EO to DL was significant $(0.67, t=7.223, p<0.001)$. The loading of DL to firm performance was also significant $(0.51, t=5.766, p<0.001)$. The results support the hypothesis: DL mediates the EO-performance relationship.

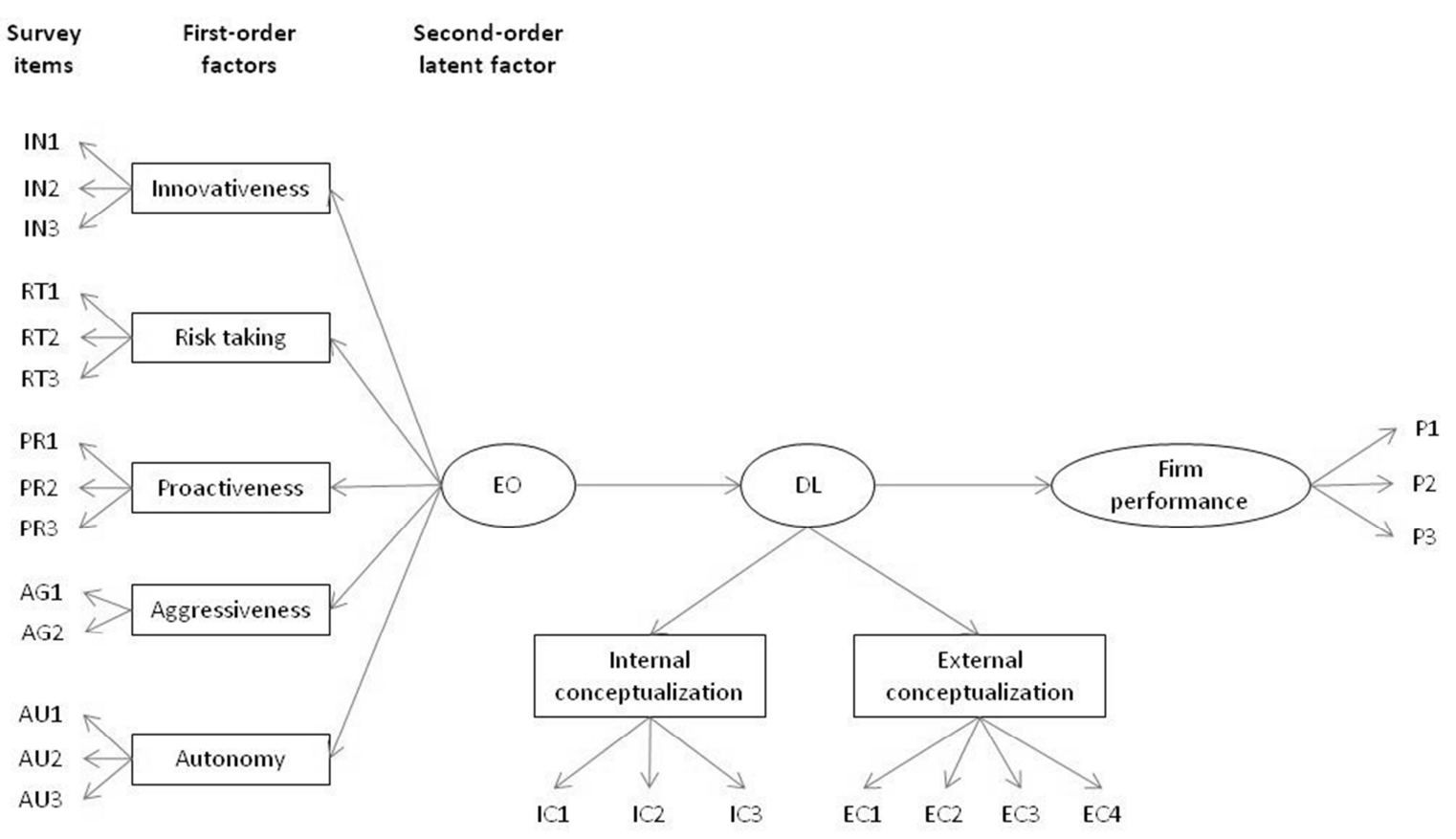

Figure 1. The Research Model.

\section{Discussion}

This study set out a task to examine the EO-DL-performance relationship. First, this study found that the EO-performance relationship was mediated by a firm's DL - a missing link in the previous literature. Secondly, this study found that risk taking, relative to innovativeness and aggressiveness, had a higher correlation coefficient in relation to the internal conceptualization of DL $(0.619,0.518$ and 0.441 , respectively). This is because risk taking and innovativeness have a stronger internal conceptualization of DL toward strategic intent. This means that, for smart competitors, the goal is not competitive imitation but competitive innovation, the art of containing competitive risks within manageable proportions (Hamel \& Prahalad, 2005). Risk tolerance is an important characteristic of entrepreneurial firms, but highly risky actions are not necessarily conducive to performance (0.217). Autonomy had the lowest correlation coefficient with internal conceptualization (0.226). The first impression is that the findings seem contradictory to Lumpkin and Dess (1996): Autonomy refers to the ability to work independently. However, a closer examination reveals that the founder-manager must be participative in the decision making process. This explains that innovativeness had a relatively high correlation with DL, because the founder-manager encourages people to think and behave in original and novel ways. In this way, the founder-manager minimizes the risk of sticky information and maximizes the possibilities of a good innovation process (Hippel, 1994).

Thirdly, the results found that aggressiveness, relative to proactiveness and risk taking, had a higher correlation coefficient with respect to external conceptualization of DL $(0.580,0.440$ and 0.422 , respectively). This is due to the fact that aggressiveness has a stronger external conceptualization of DL, meaning that rivalry among existing competitors could take many familiar forms, including price discounting, new product introductions, advertising campaigns and service improvements. Aggressiveness is an important characteristic of entrepreneurial firms, but high levels 
of rivalry limit the profitability of an industry (Porter, 1979) and are not necessarily conducive to performance (0.198). Autonomy had again the lowest correlation coefficient with external conceptualization $(0.280)$. This explains that proactiveness had a relatively high correlation with DL because the founder-manager encourages people to focus their efforts on relevant events of the environment, putting emphasis on the information of competitors, suppliers, clients and business in general, as well as the development of the market in order to obtain useful information for taking decisions (Kannan, 2002).

Finally, among the first-order factors of DL, internal conceptualization (people, culture, and product and brand) had a higher correlation than external conceptualization (competitor, customers and consumer, and technology) with firm performance ( 0.547 and 0.388 , respectively). This is consistent with the theory that although EO creates a fertile internal environment, in small firms an entrepreneurial vision must be shared effectively among all organizational members in order to bring about a positive effect on performance (Harrison \& Leitch, 2005). Failing this, the reality of a small firm would be featured by highly enthusiastic and committed individuals pulling the firm toward different directions (Wang, 2008). In this perspective, Alvarez and Busenitz (2001) stated the importance of the founder-manager's organizational ability to recombine homogeneous inputs into heterogeneous outputs. Hence, internal conceptualization is a crucial element in the mediating role of DL in the EO-performance relationship.

\section{Research Limitations}

As in any study, the findings of this paper must be viewed in light of its boundaries and limitations. Conceptually, this study developed a research model and articulated the EO-DLperformance relationship in a particular way to capture the characteristics of new ventures. Given the difficulty of operationalizing the concept of DL for empirical research, future research must endeavor to develop an effective measurement for DL that conceptually captures the perception and information processing in order to make strategic decisions. The concept of DL could provide an explanation for the phenomenon that some firms are either able to anticipate fundamental changes in their core business or are able to react to such changes earlier and more successfully than other firms within that industry.

Methodologically, this study relied on self-reported data from single informants (foundermanagers). Although the one-factor test (Podsakoff \& Organ, 1986) results indicated that common method bias is not a major problem in this study, the interpretation of the findings still have to be viewed in light of this limitation. Moreover, given that the sample of this study included only new and small ventures, this study did not monitor the kind of industrial manufacturing segment in the examination of hypothesized relationships. Future research should include a more homogeneous sample, controlling this factor. Finally, three indicators were used to measure firm performance as substitutes in the absence of hard data. This is a subjective measure that relied on self-reported data from single informants. Despite the limitations, this study contributes to the EO-performance relationship by providing empirical evidence to support the assumption that DL moderates the effect of EO on firm performance.

\section{Conclusions}

In conclusion, to argue that new ventures must learn to act entrepreneurially is no longer a novelty, and the reasons are generally well known (Zahra, Jennings, \& Kuratko, 1999). The findings of this study enhance the understanding of the EO-performance relationship in new ventures in several aspects. First, DL is an important mediator in the EO-performance relationship. This is consistent with 
Wang's (2008) advice. Future research examining the EO-performance relationship in micro or small firms must take into account individual entrepreneurs' learning, which plays a key role in the firm's learning process.

Second, risk taking, aggressiveness and innovativeness (first-order factors of EO) had the highest correlations with DL. This is consistent with Ireland, Hitt and Sirmon's (2003) observations on the concept of strategic entrepreneurship, because effective entrepreneurial firms allow strategy to form or emerge as entrepreneurial opportunities arise (or are created through strategic innovativeness). As argued by Mintzberg and Waters (1985), strategy formation in an emergent mode is often advisable because it enables firms to manage the uncertainty inherent to their operations. Innovative firms encourage people to seek unusual and novel solutions (Kuratko, Ireland, \& Hornsby, 2001), something very important in new ventures (Shane \& Venkataraman, 2000). The current results suggest that a DL must focus on identifying and implementing appropriate strategic processes that may be useful to maximize the effect of $\mathrm{EO}$ on firm performance.

Third, the results reveal that DL in new ventures must develop a vision and, above all, communicate it to people at different levels. Without a focus, entrepreneurial efforts are thinned without reaping the performance benefits (Ulrich, 2007). Yet, for DL to result in performance advantages, it also needs to be properly and successfully managed within the organization, which involves exploiting opportunities through the development and deployment of resources across organizational units (Kuratko, Ireland, Covin, \& Hornsby, 2005).

Fourth, the recent emergence of cognitive approaches to understanding how entrepreneurs think and make strategic decisions is showing much promise (Brigham, De Castro, \& Shepherd, 2007; Mitchell et al., 2002). If entrepreneurs do indeed have a unique mindset or orientation, then it follows that their cognitive approaches are likely to have strengths and weaknesses in various competitive environments and are a potential source of competitive advantage (Barney, 1991). Finally, entrepreneurship is today perceived as a heterogeneous phenomenon, complex and multidimensional. By understanding the EO-DL-performance relationship that promotes entrepreneurial behavior we verify the importance of entrepreneurial process within new ventures.

\section{Received 21 September 2010; received in revised form 8 February 2011.}

\section{References}

Aloulou, W., \& Fayolle, A. (2005). A conceptual approach of entrepreneurial orientation with small business context. Journal of Enterprising Culture, 13(1), 21-45. doi: $10.1142 / \mathrm{S} 0218495809000254$

Alvarez, S. A., \& Busenitz, L. W. (2001). The entrepreneurship of resource-based theory. Journal of Management, 27(6), 755-775. doi: 10.1177/014920630102700609

Anderson, J. C., \& Gerbing, D. W. (1988). Structural equation modeling in practice: a review and recommended two-step approach. Psychlogical Bulletin, 103(3), 411-423. doi: 10.1037/00332909.103.3.411

Andrews, K. R. (1980). The concept of corporate strategy (2nd ed.). Homewood, IL: Richard D. Irwin.

Armstrong, J. S., \& Overton, T. S. (1977). Estimating nonresponse bias in mail surveys. Journal of Marketing Research, 14(3), 396-402. doi: 10.2307/3150783

Barney, J. B. (1991). Firm resources and sustained competitive advantage. Journal of Management, 17(1), 99-110. doi: 10.1177/014920639101700108 
Bentler, P. M. (1992). EQS structural equations program manual. Los Angeles: BMDP Statistical Software.

Bettis, R. A., \& Prahalad, C. K. (1995). The dominant logic: retrospective and extension. Strategic Management Journal, 16(1), 5-14. doi: 10.1002/smj.4250160104

Bhuian, S. N., Menguc, B., \& Bell, S. J. (2005). Just entrepreneurial enough: the moderating effect of entrepreneurship on the relationship between market orientation and performance. Journal of Business Research, 58(1), 9-17. doi: 10.1016/S0148-2963(03)00074-2

Birley, S., \& Westhead, P. (1990). Growth and performance contrasts between "types" of small firms. Strategic Management Journal, 11(7), 535-557. doi: 10.1002/smj.4250110705

Bouwen, R., \& Fry, R. (1991). Organizational innovation and learning. International Studies of Management and Organization, 21(4), 37-52.

Brigham, K. H., De Castro, J. O., \& Shepherd, D. A. (2007). A person-organization fit model of owner manager's cognitive style and organizational demands. Entrepreneurship Theory and Practice, 31(1), 29-51. doi: 10.1111/j.1540-6520.2007.00162.x

Brown, T. E., Davidsson, P., \& Wiklund, J. (2001). An operationalization of Stevenson's conceptualization of entrepreneurship as opportunity-based firm behavior. Strategic Management Journal, 22(10), 953-968. doi: 10.1002/smj.190

Brush, C. G., \& Vanderwerf, P. A. (1992). A comparison of methods and sources for obtaining estimates of new venture performance. Journal of Business Venturing, 7(2), 157-170. doi: 10.1016/0883-9026(92)90010-O

Cooper, A. C. (1993). Challenges in predicting new firm performance. Journal of Business Venturing, 8(3), 241-254. doi: 10.1016/0883-9026(93)90030-9

Coté, L., Langley, A., \& Pasquero, J. (1999). Acquisition strategy and dominant logic in an engineering firm. Journal of Management Studies, 36(7), 919-952. doi: 10.1111/14676486.00164

Covin, J. G., Green, K. M., \& Slevin, D. P. (2006). Strategic process effects on the entrepreneurial orientation-sales growth rate relationship. Entrepreneurship Theory and Practice, 30(1), 57-81. doi: 10.1111/j.1540-6520.2006.00110.x

Covin, J. G., \& Slevin, D. P. (1988). The influence of organization structure on the utility of an entrepreneurial top management style. Journal of Management Studies, 25(3), 217-234. doi: 10.1111/j.1467-6486.1988.tb00033.x

Covin, J. G., \& Slevin, D. P. (1989). Strategic management of small firms in hostile and beningn environments. Strategic Management Journal, 10(1), 75-87. doi: 10.1002/smj.4250100107

Covin, J. G., \& Slevin, D. P. (1991). A conceptual model of entrepreneurship as firm behavior. Entrepreneurship Theory and Practice, 16(1), 7-25.

Davidsson, P., Low, M. B., \& Wright, M. (2001). Editor's introduction: low and MacMillan ten years on: achievements and future directions for entrepreneurship research. Entrepreneurship Theory and Practice, 25(4), 5-15. doi: 10.1177/1056492601103005

Dess, G. G., Lumpkin, G. T., \& McGee, J. E. (1999). Linking corporate entrepreneurship to strategy, structure, and process: suggested research directions. Entrepreneurship Theory and Practice, 23(3), 85-102. 
Dess, G. G., \& Robinson, R. B., Jr. (1984). Measuring organizational performance in the absence of objective measures: the case of the privately-held firm and conglomerate business unit. Strategic Management Journal, 5(3), 265-273. doi: 10.1002/smj.4250050306

Douglas, E. T. (2005). Top management team international dominant logic: a new linkage in the international diversification-performance link. Problems and Perspectives in Management, $2(1), 54-63$.

Drucker, P. (1985). Entrepreneurship and innovation. New York: Harper and Row.

Fayolle, A., Basso, O., \& Legrain, T. (2008). Corporate culture and values: genesis and sources of L'Oréal's entrepreneurial orientation. Journal of Small Business and Entrepreneurship, 21(2), 215-230.

Gartner, W. B. (1985). A conceptual framework for describing the phenomenon of new venture creation. Academy of Management Review, 10(4), 696-706. doi: 10.2307/258039

Ginsberg, A. (1990). Connecting diversification to performance: a sociocognitive approach. Academy of Management Review, 15(3), 514-535. doi: 10.2307/258021

Grant, R. M. (1988). On dominant logic, relatedness and the link between diversity and performance. Strategic Management Journal, 9(6), 639-642. doi: 10.2307/2486696

Halvorsen, C. J. M. (2006). Applying the dominant logic construct to MNCS: an epistemic representation of the global firm. Academy of Management Proceedings, D1-D6. doi: 10.5465/AMBPP.2006.22898128

Hamel, G. (2000). Leading the revolution. Cambridge, MA: Harvard University Press.

Hamel, G., \& Prahalad, C. K. (1994). Competing for the future. Harvard Business Review, 72(4), 122128.

Hamel, G., \& Prahalad, C. K. (2005). Strategic intent. Harvard Business Review, 83(7-8), 148-161.

Harrison, R. T., \& Leitch, C. M. (2005). Entrepreneurial learning: researching the interface between learning and the entrepreneurial context. Entrepreneurship Theory and Practice, 29(4), 351371. doi: 10.1111/j.1540-6520.2005.00089.x

Hippel, E. von (1994). Sticky information and the locus of problem solving: implications for innovation. Management Science, 40(4), 429-439. doi: 10.1287/mnsc.40.4.429

Hurt, H. T., Joseph, K., \& Cook, C. D. (1977). Scales for the measurement of innovativeness. Human Communication Research, 4(1), 58-65. doi: 10.1111/j.1468-2958.1977.tb00597.x

Ireland, R. D., Hitt, M. A., \& Sirmon, D. G. (2003). A model of strategic entrepreneurship: the construct and its dimensions. Journal of Management, 29(6), 963-989. doi: 10.1016/S01492063(03)00086-2

Jöreskog, K. G., \& Sörbom, D. (1996). LISREL 8: the simplis command language. Chicago: Scientific Software International.

Kannan, P. K. (2002). Web-based analysis for competition intelligence. Journal of Marketing Research, 34(2), 274-275.

Kazanjian, R. K., \& Drazin, R. (1990). A stage-contingent model of design and growth for technology based ventures. Journal of Business Venturing, 5(3), 137-150. doi: 10.1016/08839026(90)90028-R 
Krogh, G. von, \& Roos, J. (1996). A tale of the unfinished. Strategic Management Journal, 17(9), 729-737. doi: 10.1002/(SICI)1097-0266(199611)17:9<729::AID-SMJ850>3.0.CO;2-1

Krogh, G. von, Erat, P., \& Macus, M. (2000). Exploring the link between dominant logic and company performance. Creativity and Innovation Management, 9(2), 82-93. doi: 10.1111/14678691.00160

Kuratko, D. F., Ireland, R. D., Covin, J. G., \& Hornsby, J. S. (2005). A model of middle-level manager's entrepreneurial behavior. Entrepreneurship Theory and Practice, 29(6), 699-716. doi: $10.1111 / j .1540-6520.2005 .00103 . x$

Kuratko, D. F., Ireland, R. D., \& Hornsby, J. S. (2001). Improving firm performance through entrepreneurial actions: Acordia's corporate entrepreneurship strategy. Academy of Management Executive, 15(4), 60-71. doi: 10.2307/4165786

Lampel, J., \& Shamsie, J. (2000). Probing the unobtrusive link: dominant logic and the design of joint ventures at general electric. Strategic Management Journal, 21(5), 593-603. doi: 10.1002/(SICI)1097-0266(200005)21:5<593::AID-SMJ100>3.0.CO;2-0

Littunen, H., Storhammar, E., \& Nenonen, T. (1998). The survival of firms over the critical first 3 year and the local environment. Entrepreneurship and Regional Development, 10(3), 189-203. doi: $10.1080 / 08985629800000011$

Lumpkin, G. T., Cogliser, C. C., \& Schneider, D. R. (2009). Understanding and measuring autonomy: an entrepreneurial orientation perspective. Entrepreneurship Theory and Practice, 33(1), 47-69. doi: $10.1111 / \mathrm{j} .1540-6520.2008 .00280 . \mathrm{x}$

Lumpkin, G. T., \& Dess, G. G. (1996). Clarifying the entrepreneurial orientation construct and linking it to performance. Academy of Management Review, 21(1), 135-172. doi: 10.2307/258632

Lumpkin, G. T., \& Dess, G. G. (2001). Linking two dimensions of entrepreneurial orientation to firm performance: the moderating role of environmental and industry life cycle. Journal of Business Venturing, 16(5), 429-451. doi: 10.1016/S0883-9026(00)00048-3

Lyon, D. W., Lumpkin, G. T., \& Dess, G. G. (2000). Enhancing entrepreneurial orientation research: operationalizing and measuring a key strategic decision making process. Journal of Management, 26(5), 1055-1085. doi: 10.1016/S0149-2063(00)00068-4

MacKinnon, D. P., Lockwood, C. M., Hoffman, J. M., West, S. G., \& Sheets, V. (2002). A comparison of methods to test mediation and other intervening variables effects. Psychological Methods, 7(1), 83-104. doi: 10.1037//1082-989X.7.1.83

March, J. (1994). A primer on decision making. New York: Free Press.

McMullen, J. S., \& Shepherd, D. A. (2006). Entrepreneurial action and the role of uncertainty in the theory of the entrepreneur. Academy of Management Review, 31(1), 132-152. doi: $10.2307 / 20159189$

Miller, C., Burke, L., \& Glick, W. (1998). Cognitive diversity among upper-echelon executives: implications for strategic decision processes. Strategic Management Journal, 19(1), 39-58. doi: 10.1002/(SICI)1097-0266(199801)19:1<39::AID-SMJ932>3.0.CO;2-A

Miller, D. (1983). The correlates of entrepreneurship in three types of firms. Management Science, 29(7), 770-791. doi: 10.1287/mnsc.29.7.770

Miller, D., \& Friesen, P. H. (1982). Innovation in conservative and entrepreneurial firms: two models of strategic momentum. Strategic Management Journal, 3(1), 1-25. doi: 10.1002/smj.4250030102 
Mintzberg, H., \& Waters, J. A. (1985). Of strategies, deliberate and emergent. Strategic Management Journal, 6(3), 257-272. doi: 10.2307/2486186

Mitchell, R., Busenitz, L., Lant, T., McDougall, P., Morse, E., \& Smith, B. (2002). Toward a theory of entrepreneurial cognition: rethinking the people side of entrepreneurship research. Entrepreneurship Theory and Practice, 27(2), 93-104. doi: 10.1111/1540-8520.00001

Naman, J. L., \& Slevin, D. P. (1993). Entrepreneurship and the concept of fit: a model and empirical test. Strategic Management Journal, 14(2), 137-153. doi: 10.1002/smj.4250140205

Peter, J. P. (1979). Reliability: a review of psychometric basics and recent marketing practices. Journal of Marketing Research, 16(1), 6-17. doi: 10.2307/3150868

Podsakoff, P. M., \& Organ, D. W. (1986). Self-reports in organizational research: problems and prospects. Journal of Management, 12(4), 531-544. doi: 10.1177/014920638601200408

Porter, M. E. (1979). How competitive forces shape strategy. Harvard Business Review, 57(2), 137145.

Prahalad, C. K., \& Bettis, R. A. (1986). The dominant logic: a new linkage between diversity and performance. Strategic Management Journal, 7(6), 485-501. doi: 10.2307/2486135

Prahalad, C. K., \& Krishnan, M. S. (2008). The new age of innovation. New York: McGraw-Hill.

Premkumar, G., \& King, W. R. (1994). Organizational characteristics and information systems planning: an empirical study. Information Systems Research, 5(2), 75-109. doi: 10.1287/isre.5.2.75

Rauch, A., Wiklund, J., Lumpkin, G. T., \& Frese, M. (2009). Entrepreneurial orientation and business performance: an assessment of past research and suggestions for the future. Entrepreneurship Theory and Practice, 33(3), 761-787. doi: 10.1111/j.1540-6520.2009.00308.x

Richard, O. C., Barnett, T., Dwyer, S., \& Chadwick, K. (2004). Cultural diversity in management, firm performance, and the moderating role of entrepreneurial orientation dimensions. Academy of Management Journal, 47(2), 255-268. doi: 10.2307/20159576

Rosenberg, M. (1968). The logic of survey analysis. New York: Basic Books.

Schein, E. H. (1983). The role of the founder in creating organizational culture. Organizational Dynamics, 12(1), 13-28. doi: 10.1016/0090-2616(83)90023-2

Shane, S. (2009). Technology strategy for managers and entrepreneurs. Englewood Cliffs, NJ: Prentice Hall.

Shane, S., \& Venkataraman, S. (2000). The promise of entrepreneurship as a field of research. Academy of Management Review, 25(1), 217-226. doi: 10.2307/259271

Stevenson, H. H., \& Jarillo, J. C. (1990). A paradigm of entrepreneurship: entrepreneurial management. Strategic Management Journal, 11(5), 17-27. doi: 10.1007/3-540-48543-0_7

Ulrich, W. (2007). Firms as realizations of entrepreneurial visions. Journal of Management Studies, 44(7), 1125-1140. doi: 10.1111/j.1467-6486.2007.00731.x

Walter, A., Auer, M., \& Ritter, T. (2005). The impact of network capabilities and entrepreneurial orientation on university spin-off performance. Journal of Business Venturing, 21(4), 541-567. doi: 10.1016/j.jbusvent.2005.02.005 
Wang, C. L. (2008). Entrepreneurial orientation, learning orientation, and firm performance. Entrepreneurship Theory and Practice, 32(4), 635-657. doi: 10.1111/j.1540-6520.2008.00246.x

Wiklund, J. (1999). The sustainability of the entrepreneurial orientation-performance relationship. Entrepreneurship Theory and Practice, 24(1), 37-48.

Wiklund, J., \& Shepherd, D. (2003). Knowledge-based resources, entrepreneurial orientation, and the performance of small and medium sized business. Strategic Management Journal, 24(13), 13071314. doi: $10.1002 / \mathrm{smj} .360$

Wiklund, J., \& Shepherd, D. (2005). Entrepreneurial orientation and small business performance: a configurational approach. Journal of Business Venturing, 20(1), 71-91. doi: 10.1016/j.jbusvent.2004.01.001

Zahra, S. A. (1993). A conceptual model of entrepreneurship as firm behavior: a critique and extension. Entrepreneurship Theory and Practice, 17(4), 5-21.

Zahra, S. A., \& Covin, J. G. (1995). Contextual influences on the corporate entrepreneurship performance relationship: a longitudinal analysis. Journal of Business Venturing, 10(1), 43-58. doi: 10.1016/0883-9026(94)00004-E

Zahra, S. A., \& Garvis, D. M. (2000). International corporate entrepreneurship and firm performance: the moderating effect of international environmental hostility. Journal of Business Venturing, 15(5-6), 469-492. doi: 10.1016/S0883-9026(99)00036-1

Zahra, S. A., Jennings, D. F., \& Kuratko, D. F. (1999). The antecedents and consequences of firmlevel entrepreneurship: the state of the field. Entrepreneurship Theory and Practice, 24(2), 4565. doi: 10.1016/S0267-3649(00)88914-1 


\section{APPENDIX}

Table A1

The Entrepreneurial Orientation Scale

\begin{tabular}{|c|c|c|}
\hline First Order Factor & Code & Statement \\
\hline \multirow[t]{3}{*}{ Innovativeness } & IN1 & $\begin{array}{l}\text { Management actively responds to main competitors' new ways of doing } \\
\text { things. }\end{array}$ \\
\hline & IN2 & $\begin{array}{l}\text { We are willing to try new ways of doing things and seek unusual, novel } \\
\text { solutions. }\end{array}$ \\
\hline & IN3 & We encourage people to think and behave in original and novel ways \\
\hline \multirow[t]{3}{*}{ Risk taking } & RT1 & $\begin{array}{l}\text { In general, the people of my organization have a strong propensity for } \\
\text { high-risk projects. }\end{array}$ \\
\hline & RT2 & $\begin{array}{l}\text { Our people believe, owing to the nature of the environment, that bold, } \\
\text { wide-ranging acts are necessary to achieve our organization objectives. }\end{array}$ \\
\hline & RT3 & $\begin{array}{l}\text { When there is uncertainty, our organization typically adopts a "wait-and- } \\
\text { see" posture in order to minimize the probability of making costly } \\
\text { decisions. (Reverse coded). }\end{array}$ \\
\hline \multirow[t]{3}{*}{ Proactiveness } & PR1 & $\begin{array}{l}\text { In general, the people of our organization favor a strong emphasis on } \\
\text { Research \& Development, technological leadership, and innovations. }\end{array}$ \\
\hline & PR2 & $\begin{array}{l}\text { In the past } 3 \text { years, our organization has marketed a wide variety of new } \\
\text { lines of products and/or services. }\end{array}$ \\
\hline & PR3 & $\begin{array}{l}\text { In the past } 3 \text { years, changes in our products and/or service lines have been } \\
\text { mostly of a minor nature. (Reverse coded). }\end{array}$ \\
\hline \multirow[t]{2}{*}{ Aggressiveness } & AG1 & $\begin{array}{l}\text { In dealing with competitors, our organization often leads the competition, } \\
\text { initiating actions to which our competitors have to respond. }\end{array}$ \\
\hline & AG2 & $\begin{array}{l}\text { In dealing with competitors, our organization typically adopts a very } \\
\text { competitive posture aiming to overtake competitors. }\end{array}$ \\
\hline \multirow[t]{3}{*}{ Autonomy } & AU1 & $\begin{array}{l}\text { The firm supports the efforts of individuals and/or teams that work } \\
\text { autonomously. }\end{array}$ \\
\hline & AU2 & $\begin{array}{l}\text { In general, the people of my firm believe that: the best results occur when } \\
\text { individuals and/or teams decide for themselves what business } \\
\text { opportunities to pursue. }\end{array}$ \\
\hline & AU3 & $\begin{array}{l}\text { Individuals and/or teams pursuing business opportunities make decisions } \\
\text { on their own without constantly referring to their supervisor(s). }\end{array}$ \\
\hline
\end{tabular}

Note. Respondents were given instructions to indicate a number (ranging from 1, "strongly disagree" to 7, "strongly agree") that corresponded to their agreement with each of the statements mentioned above. 
Table A2

The Dominant Logic Scale

\begin{tabular}{lll}
\hline First Order Factor & Code & \multicolumn{1}{c}{ Statement } \\
\hline Internal conceptualization & IC1 & I have told each person the importance of their role in the company. \\
IC2 & $\begin{array}{l}\text { I constantly ask employees to check that their habits and their } \\
\text { working manner favor the achievement of the objectives of the } \\
\text { company. }\end{array}$ \\
IC3 & $\begin{array}{l}\text { It is fundamental that our products have distinctive characteristics } \\
\text { in relation to other options, so they may be clearly identified within } \\
\text { the industry for their quality }\end{array}$ \\
External conceptualization & EC1 & $\begin{array}{l}\text { It is fundamental to pay attention to the signals that the market } \\
\text { generates, in order for us to take advantage of business } \\
\text { opportunities. }\end{array}$ \\
EC2 & $\begin{array}{l}\text { It is essential to keep an eye on the action our competitors } \\
\text { undertake in order to take timely decisions. }\end{array}$ \\
EC3 & $\begin{array}{l}\text { Our priority is to satisfy our clients' expectations. } \\
\text { EC4 }\end{array}$ & $\begin{array}{l}\text { The technology we use allows us to offer higher quality products } \\
\text { and services than those of our competitors. }\end{array}$ \\
\hline
\end{tabular}

Note. Respondents were given instructions to indicate a number (ranging from 1, strongly disagree to 7 , strongly agree) that corresponded to their agreement with each of the statements mentioned above.

Table A3

\section{The Performance Scale}

\begin{tabular}{rlr}
\hline Code & & Statement \\
\hline P1 & Cash flow from operations & \\
P2 & Return on capital employed & \\
P3 & Sales growth \\
\hline
\end{tabular}

Note. Respondents were given instructions to indicate a number (ranging from 1, "not all satisfactory" to 7, "outstanding") that corresponded to their agreement with each of the statements given above. 